\title{
Oral iron versus intravenous ferric carboxymaltose in the treatment of iron deficiency anemia in pregnancy: a retrospective study
}

\author{
Şule Yıldız (D), Engin Türkgeldi \\ Department of Obstetrics and Gynecology, School of Medicine, Koç University, Istanbul, Turkey
}

\begin{abstract}
Objective: Pregnant women with iron deficiency and severe anemia are at increased risk of preterm delivery, prematurity, and small for gestational age. Increased iron requirement necessitates iron replacement during pregnancy. While oral iron supplements are the common first choice, up to two-thirds of women experience doselimiting gastrointestinal side effects. Hence, intravenous iron can be an alternative method for iron replacement. We aimed to compare women who were given oral iron with women who received ferric carboxymaltose during pregnancy with regard to change in hemoglobin $(\mathrm{Hb})$ and hematocrit $(\mathrm{Hct})$ levels, mean corpuscular volume (MCV), weight gain during pregnancy, gestational age at birth, delivery method and birthweight.

Methods: A total of 120 pregnant women, 60 in the oral iron group and 60 in the ferric carboxymaltose group were included in this retrospective study. All pregnant women underwent a baseline measurement for $\mathrm{Hb}, \mathrm{MCV}$, and Hct levels at their first antepartum care visit in the first trimester. Women in the oral iron group were started supplementation between the 16 and 20 weeks of gestation. Women in the ferric carboxymaltose group underwent $1000 \mathrm{mg}$ of iron infusion between 20 and 28 weeks of gestation.

Results: Women in the oral iron group have shown a significant decrease in $\mathrm{Hb}$ levels which was 12.2 (range: $11.5-13$ ) $\mathrm{g} / \mathrm{dL}$ at baseline and 12.1 (range: $11.2-12.5) \mathrm{g} / \mathrm{dL}$ before delivery $(\mathrm{p}=0.034)$. However, ferric carboxymaltose group did not show any difference between baseline $\mathrm{Hb}$ levels and $\mathrm{Hb}$ levels before delivery $(\mathrm{p}=0.60)$. Likewise, Hct levels have shown a significant decrease in the oral iron group which were 36.7 (range: 34-39) and 35.8 (range: 34-38) at baseline and before delivery, respectively $(\mathrm{p}=0.006)$. There was no significant difference between Hct levels in the ferric carboxymaltose group.

Conclusion: Intravenous ferric carboxymaltose administration seems an effective, easy-to-use option for iron supplementation during pregnancy.
\end{abstract}

Keywords: Intravenous ferric carboxymaltose; oral iron; iron deficiency in pregnancy, anemia in pregnancy.
Özet: Gebelikte demir eksikliği anemisinin tedavisinde oral demire karșı intravenöz ferrik karboksimaltoz: Retrospektif çalışma

Amaç: Demir eksikliği ve şiddetli anemisi olan gebeler, preterm doğum, prematürite ve gebelik haftasına göre küçük olma yönünden artmış risk altındadır. Artmıs demir gereksinimi, gebelikte demir replasmanını gerekli kılmaktadır. Oral demir takviyeleri yaygın ilk tercihken, kadınların üçte ikisine kadar olan kısmı doz sınırlayıcı gastrointestinal yan etkiler yaşamaktadır. Bu nedenle, demir replasma$\mathrm{n}$ için intravenöz demir alternatif bir yöntem olabilir. Çalışmamız$\mathrm{da}$, hemoglobin $(\mathrm{Hb})$ ve hematokrit (Hct) seviyelerinde değişim, ortalama eritrosit hacmi (MCV), gebelikte kilo alma, doğumda gestasyonel yaş, doğum yöntemi ve doğum ağırlığı yönünden gebelik süresince oral demir alan kadınlarla ferrik karboksimaltoz alan kadınları karşılaştırmayı amaçladık.

Yöntem: Bu retrospektif çalışmaya, altmışı oral demir grubu ve altmış ferrik karboksimaltoz grubunda olmak üzere toplam 120 gebe dahil edildi. Tüm gebelere, birinci trimesterdeki ilk antepartum bakım ziyaretlerinde $\mathrm{Hb}, \mathrm{MCV}$ ve Hct seviyeleri için referans ölçümü yapıldı. Oral demir grubundaki kadınlara 16. ve 20. gebelik haftaları arasında takviye başlandı. Ferrik karboksimaltoz grubundaki kadınlara 20. ve 28. gebelik haftaları arasında $100 \mathrm{mg}$ demir infüzyonu uygulandi.

Bulgular: Oral demir grubundaki kadınlarda $\mathrm{Hb}$ seviyelerinde anlamlı bir azalma görüldü; referans ölçümünde 12.2 (aralık: 11.5-13) g/dL ve doğumdan önce 12.1 (aralık: 11.2-12.5) g/dL idi. Ancak ferrik karboksimaltoz grubunda referans $\mathrm{Hb}$ seviyeleri ile doğumdan önceki $\mathrm{Hb}$ seviyeleri arasında herhangi bir fark görülmedi $(\mathrm{p}=0.60)$. Benzer şekilde Hct seviyelerinde de oral demir grubunda anlamlı azalma görüldü; referans ölçümünde ve doğumdan önce s1rasiyla 36.7 (aralık: 34-39) ve 35.8 (aralık: 34-38) idi ( $\mathrm{p=0.006)}$ Ferrik karboksimaltoz grubunda Hct seviyeleri arasinda anlaml fark yoktu.

Sonuç: İntravenöz ferrik karboksimaltoz uygulamasının, gebelik süresince demir takviyesi olarak verimli ve kullanımı kolay bir seçenek olduğu görülmektedir.

Anahtar sözcükler: İntravenöz ferrik karboksimaltoz; oral demir; gebelikte demir eksikliği, gebelikte anemi.

Correspondence: Şule Yıldız, MD. Department of Obstetrics and Gynecology, School of Medicine, Koç University, Istanbul, Turkey.

e-mail: yildizsuledr@gmail.com / Received: September 21, 2021; Accepted: October 31, 2021

How to cite this article: Yıldız Ş, Türkgeldi E. Oral iron versus intravenous ferric carboxymaltose in the treatment of iron deficiency anemia in pregnancy: a retrospective study. Perinatal Journal 2021;29(3):194-199. doi:10.2399/prn.21.0293004

ORCID ID: Ş. Yıldız 0000-0002-4803-7043; E. Türkgeldi 0000-0002-5008-3292 


\section{Introduction}

Hemoglobin $(\mathrm{Hb})$ concentration $<11 \mathrm{~g} / \mathrm{dL}$ in the first trimester or $<10 \mathrm{~g} / \mathrm{dL}$ in the second and third trimesters are defined as significant anemia in pregnancy. ${ }^{[1,2]}$ Iron deficiency is the most common cause of anemia in pregnancy and affects $2-26 \%$ of pregnant women depending on the population screened. ${ }^{[1,3,4]}$ Iron deficiency can be diagnosed by serum ferritin-level measurement (threshold value $<30 \mu \mathrm{g} / \mathrm{L}){ }^{[5]}$

Patients with iron deficiency may present with fatigue, headache, low physical and mental capacity, vertigo, leg cramps, pagophagia, cold intolerance, koilonychia, mucosal paleness, and angular stomatitis. ${ }^{[6]}$ Besides, pregnant women with iron deficiency and severe anemia are at increased risk of preterm delivery, prematurity, and small for gestational age. ${ }^{[7]}$

Increased iron requirement necessitates iron replacement in pregnant women. The American College of Obstetricians and Gynecologists (ACOG) recommends low-dose iron supplementation with 27 to $30 \mathrm{mg}$ iron during pregnancy ${ }^{[8]}$ While oral iron supplements are the common first choice, up to two-thirds of women experience dose-limiting gastrointestinal side effects. Hence, intravenous iron can be an alternative method for iron replacement. ${ }^{[0]}$

Ferric carboxymaltose solution comprises a polynuclear iron (III)-(oxyhydr)oxide core stabilized by carboxymaltose. ${ }^{[10]}$ While former intravenous iron preparations had the risk of serious side effects such as anaphylactic shock, ferric carboxymaltose is safer with carbohydrate shells ensuring the slower release of iron. ${ }^{[11]}$ Different studies comparing different intravenous iron formulations have suggested that when high molecular weight iron dextran is avoided intravenous iron seems safe with a risk of serious events $<1: 200,000 .{ }^{[12]}$ A recent clinical trial comparing ferric carboxymaltose and oral iron in patients with iron deficiency anemia following childbirth has suggested that ferric carboxymaltose is a safe and effective option. ${ }^{[13]}$

In this study, we aimed to investigate whether single intravenous ferric carboxymaltose administration was as effective as 6-month oral iron supplementation in pregnant women with iron deficiency anemia.

\section{Methods}

This retrospective study was conducted in accordance with the Declaration of Helsinki Ethical Principles and
Good Clinical Practices and the protocol of this retrospective study was approved by Koç University Clinical Research Ethics Committee (2021.280.IRB1.098).

In our unit, either oral $\mathrm{Fe}^{+2}$ iron or intravenous ferric carboxymaltose is prescribed for women with ferritin levels $<30 \mathrm{ng} / \mathrm{ml}$ at the discretion of the physician in charge. For our study, we screened our electronic patient records and included all women who were given intravenous ferric carboxymaltose at Koç University Hospital Department of Obstetrics and Gynecology, between January 2020 and May 2020. These were matched according to their baseline $\mathrm{Hb}$ levels with 60 women who were supplemented with oral $\mathrm{Fe}^{+2}$ iron during the same period. We excluded women with other causes of anemia, vitamin B12 or folate deficiency, multiple pregnancy, or preterm birth.

All pregnant women underwent a baseline measurement for $\mathrm{Hb}$, mean corpuscular volume (MCV), and hematocrit (Hct) levels at their first antepartum care visit in the first trimester. Also, we evaluated serum ferritin levels immediately before iron supplementation in both groups. Iron deficiency is defined with ferritin levels $<30$ $\mathrm{ng} / \mathrm{mL} \cdot{ }^{[14]}$ Women in the oral iron group were started $\mathrm{Fe}^{+2}$ iron supplementation between 16 and 20 weeks of gestation if ferritin levels $<30 \mathrm{ng} / \mathrm{mL}$ or $\mathrm{Hb}$ level $<11$ $\mathrm{g} / \mathrm{dL}$ at their visit. Women in the ferric carboxymaltose group underwent $1000 \mathrm{mg}$ of iron infusion between the 20 and 28 weeks of gestation with ferric carboxymaltose.

The primary outcome was the change in $\mathrm{Hb}$ and $\mathrm{Hct}$ levels before and after iron supplementation. We recorded body mass index (BMI), weight gain during pregnancy, serum ferritin levels before iron treatment, $\mathrm{Hb}$, MCV, and Hct levels before and after iron treatment, gestational age at birth, delivery method, and fetal weight at birth in both groups.

The distribution of each variable was evaluated with a histogram. Continuous variables were defined with median (25th and 75th percentiles) and compared between the groups using Mann-Whitney $U$ or unpaired t-test depending on the distribution assumptions. Categorical variables were presented as numbers and percentages. Comparisons were made with Chi-squared or Fisher's exact test for categorical variables. A two-sided p-value $<0.05$ was considered statistically significant.

Statistical analysis was performed with Statistical Package for Social Sciences (SPSS) software Version 28.0 (IBM SPSS Statistics, Armonk, NY, USA). 


\section{Results}

A total of 120 pregnant women, 60 in the oral iron treatment group and 60 in the ferric carboxymaltose treatment group were included. Baseline characteristics are shown in Table $\mathbf{1}$. The median age was 30 (range: 28-34.8) years in the oral iron treatment group and 34 (range: 30-37) years in the ferric carboxymaltose group $(\mathrm{p}<0.01)$. Median BMI levels were 21.9 (range: $19.2-24.7) \mathrm{kg} / \mathrm{m}^{2}$ in oral iron treatment group and 22.9 (range: $20.8--26.1) \mathrm{kg} / \mathrm{m}^{2}$ in ferric carboxymaltose group $(\mathrm{p}=0.12)$.

Baseline Hb levels were 12.2 (range: $11.5-13) \mathrm{mg} / \mathrm{dL}$ and 12.5 (range: $11.9-13.2) \mathrm{mg} / \mathrm{dL}$ in oral iron and ferric carboxymaltose treatment groups, respectively $(\mathrm{p}=0.22)$. However, Hb levels at delivery were significantly higher in ferric carboxymaltose group with 12.5 (range: 11.9-13.7) $\mathrm{g} / \mathrm{dL}$ compared to oral iron group with 12.1 (range: $11.2-12.5) \mathrm{g} / \mathrm{dL}(\mathrm{p}=0.002)$. Likewise, baseline Hct levels did not show any difference 36.7 (range: 34-39) vs. 37.6 (range: 35.4-39.7) ( $\mathrm{p}=0.29)$ between the groups. Median Hct levels at delivery were significantly higher in ferric carboxymaltose group which was 37 (range: 35.6-39) compared to oral iron group which was 35.8 (range: $34-38)(\mathrm{p}=0.005)$.

Ferritin levels before iron treatment in both groups are shown in Table 2 . There was no significant difference between ferritin levels immediately before treatment $(\mathrm{p}=0.08)$. We compared baseline $\mathrm{Hb}$ levels and $\mathrm{Hb}$ levels before delivery in both groups. Women in the oral iron group have shown a significant decrease in $\mathrm{Hb}$ lev- els which was 12.2 (range: $11.5-13) \mathrm{g} / \mathrm{dL}$ at baseline and 12.1 (range: $11.2-12.5) \mathrm{g} / \mathrm{dL}$ before delivery $(\mathrm{p}=0.034)$. However ferric carboxymaltose group did not show any difference between baseline $\mathrm{Hb}$ levels and $\mathrm{Hb}$ levels before delivery $(\mathrm{p}=0.60)$. Likewise, Hct levels have shown a significant decrease in the oral iron group which were 36.7 (range: 34-39) and 35.8 (range: 34-38) at baseline and before delivery, respectively $(\mathrm{p}=0.006)$. There was no significant difference between Hct levels in the ferric carboxymaltose group (Table 3).

Weight gain during pregnancy was 14 (range: $12-17$ ) $\mathrm{kg}$ in the oral iron group and 14 (range: 10-16) $\mathrm{kg}$ in the ferric carboxymaltose group $(\mathrm{p}=0.26)$. Hence BMI levels at delivery did not show a difference $(\mathrm{p}=0.13)$ same as baseline BMI levels.

Median birth weight was 3260 (range: 2983-3550) g in the oral iron group and 3090 (range: 3390-3550) $\mathrm{g}$ in the ferric carboxymaltose group $(\mathrm{p}=0.20)$. Median gestational age at birth was 273 (range: 267-278) days and 272.5 (range: 266-275.8) days in the oral and ferric carboxymaltose group, respectively $(\mathrm{p}=0.28)$. Method of delivery in oral iron group was $50 \%$ vaginal $(n=30)$ and $50 \%$ cesarean section $(n=30)$. However, vaginal birth constituted $28.3 \%(n=17)$ of the deliveries in the ferric carboxymaltose group.

Women who had ferric carboxymaltose did not experience severe side effects after the treatment. Specifically, anaphylactic reaction during ferric carboxymaltose administration did not occur. Only one woman

Table 1. Baseline characteristics of pregnant women in oral iron and ferric carboxymaltose groups.

\begin{tabular}{|c|c|c|c|}
\hline & Oral iron group & Ferric carboxymaltose group & p-value \\
\hline Age (years) & $30(28-34.8)$ & $34(30-37)$ & $<0.01$ \\
\hline \multicolumn{4}{|l|}{ Gravida } \\
\hline 1 & 29 & 33 & \multirow{3}{*}{0.16} \\
\hline 2 & 25 & 16 & \\
\hline$>2$ & 6 & 11 & \\
\hline \multicolumn{4}{|l|}{ Parity } \\
\hline 0 & 36 & 43 & \multirow{3}{*}{0.27} \\
\hline 1 & 23 & 15 & \\
\hline$>1$ & 1 & 2 & \\
\hline Baseline BMI levels $\left(\mathrm{kg} / \mathrm{m}^{2}\right)$ & $21.9(19.2-24.7)$ & $22.9(20.8-26.1)$ & 0.12 \\
\hline Baseline Hb levels ( $\mathrm{g} / \mathrm{dL}$ ) & $12.2(11.5-13)$ & $12.5(11.9-13.2)$ & 0.22 \\
\hline Baseline MCV levels & $88(84.9-90.3)$ & $86(83.1-88.6)$ & 0.05 \\
\hline Baseline Hct levels (\%) & 36.7 (34-39) & $37.6(35.4-39.7)$ & 0.29 \\
\hline
\end{tabular}


Table 2. Post-treatment characteristics of pregnant women in oral iron and ferric carboxymaltose groups.

\begin{tabular}{lccc} 
& Oral iron group & Ferric carboxymaltose group & p-value \\
\hline Ferritin levels before iron replacement & $12(10-20)$ & $10(8-18.5)$ & 0.08 \\
\hline BMl levels at delivery $\left(\mathrm{kg} / \mathrm{m}^{2}\right)$ & $27.3(25.4-29.4)$ & $28.7(26-31.2)$ & 0.13 \\
\hline Hb levels at delivery $(\mathrm{g} / \mathrm{dL})$ & $12.1(11.2-12.5)$ & $12.5(11.9-13.7)$ & $<0.01$ \\
\hline MCV levels at delivery & $88.5(85-91)$ & $88.8(86.5-91)$ & 0.21 \\
\hline Hct levels at delivery & $35.8(34-38)$ & $37(35.6-39)$ & $<0.01$ \\
\hline Difference in Hb levels $(\mathrm{g} / \mathrm{dL})^{*}$ & $-.3(.4,-.9)$ & $-.05(-.6, .7)$ & 0.06 \\
\hline Difference in Hct levels ${ }^{\dagger}$ & $-1(-3.5,1)$ & $-.2(-1.9,1.9)$ & 0.09 \\
\hline Difference in MCV levels ${ }^{\ddagger}$ & $1(-1.63,3)$ & $3(0.75-5.1)$ & $<0.01$ \\
\hline Weight gain during pregnancy $(\mathrm{kg})$ & $14(12-17)$ & $14(10-16)$ & 0.26 \\
\hline Birthweight $(\mathrm{kg})$ & $3260(2983-3550)$ & $3090(3390-3550)$ & 0.20 \\
\hline Gestational age at birth (days) & $273(267-278)$ & $272.5(266-275.8)$ & 0.28 \\
\hline Method of delivery & & & 0.02 \\
$\quad$ Vaginal birth $(\mathrm{n})$ & $50 \%(30)$ & $71.7 \%(43)$ & \\
\hline Cesarean section $(\mathrm{n})$ & $50 \%(30)$ & & \\
\hline
\end{tabular}

Note: Values are median (25th and 75th percentiles) or \% (n). *Difference between $\mathrm{Hb}$ levels at delivery and baseline $\mathrm{Hb}$ levels; ${ }^{\dagger}$ Difference between Hct levels at delivery and baseline Hct levels; ${ }^{\ddagger}$ Difference between MCV levels at delivery and baseline MCV levels.

reported a mild allergic reaction during the treatment which disappeared after the treatment.

\section{Discussion}

Our results suggest that intravenous ferric carboxymaltose is a good alternative iron supplementation for pregnant women who cannot tolerate oral iron or who have severe anemia in pregnancy. According to our findings, median $\mathrm{Hb}$ and Hct levels at delivery decreased significantly compared with baseline $\mathrm{Hb}$ and Hct levels in the oral iron group. However, in the intravenous iron group, $\mathrm{Hb}$ and Hct levels at delivery did not show a significant difference when compared to baseline Hb levels. One of the explanations could be that $\mathrm{Hb}$ and Hct levels are decreasing in both groups around 20-24 weeks of gestation. From a practical point of view, patients are eventually anemic compared to their basal levels if they use oral iron during pregnancy. However, $\mathrm{Hb}$ and $\mathrm{Hct}$ levels of women who were administered ferric carboxymaltose around 24 weeks of gestation increase until delivery and therefore we do not see that decrease in the ferric carboxymaltose group.

Intravenous iron carries a risk of anaphylaxis. ${ }^{[15]}$ In a study the risk for anaphylaxis was 68 per 100,000 persons for iron dextran (95\% CI, 57.8-78.7 per 100,000) and 24 per 100,000 persons for all nondextran intravenous iron products (95\% CI, 20.0-29.5 per 100,000) (adjusted odds ratio [OR] of 2.6 [95\% CI, 2.0-3.3; $\mathrm{p}<0.001]) .{ }^{[15]}$ However ferric carboxymaltose is an agent which can be considered safe and practical, as it does not

Table 3. Comparison of $\mathrm{Hb}$ and Hct levels before and after treatment in oral iron and ferric carboxymaltose groups.

\begin{tabular}{lccc} 
& Baseline Hb levels $(\mathbf{g} / \mathbf{d L})$ & Hb levels at delivery $(\mathbf{g} / \mathbf{d L})$ & $\mathbf{p}$-value \\
\hline Oral iron & $12.2(11.5-13)$ & $12.1(11.2-12.5)$ & 0.03 \\
\hline Ferric carboxymaltose & $12.5(11.9-13.2)$ & $12.6(11.9-13.2)$ & 0.60 \\
\hline & Baseline Hct levels (\%) & Hct levels at delivery (\%) & $\mathbf{p - v a l u e}$ \\
\hline Oral iron & $36.7(34-39)$ & $35.8(34-38)$ & $<0.01$ \\
\hline Ferric carboxymaltose & $37.6(35.4-39.7)$ & $37(35.6-39)$ & 0.58 \\
\hline
\end{tabular}


require a test dose or premedication prior to administration, and can be administered in 15 minutes without serious side effects. ${ }^{[11]} \mathrm{We}$ also did not observe any severe adverse effects in our patients following intravenous ferric carboxymaltose treatment.

Intravenous iron supplementation has been shown to improve iron-deficiency anemia and restore iron stores effectively in previous studies. ${ }^{[16,17]}$ Based on clinical trials and real patient data ferric carboxymaltose is an effective and well-tolerated agent for treating anemia in pregnant women who have iron deficiency. ${ }^{[1-21]}$ A randomized study including 90 women with hemoglobin levels between 8 and $10.5 \mathrm{~g} / \mathrm{dL}$ and ferritin values less than 13 $\mathrm{mcg} / \mathrm{L}$ compared oral iron polymaltose complex (300 mg elemental iron per day) with intravenous iron sucrose in pregnant women. Their results have shown that intravenous iron restored iron stores faster and more effectively than oral iron in iron-deficiency anemia of pregnancy, with no serious adverse reactions. ${ }^{[16]}$ Another randomized study including 100 anemic antenatal women with hemoglobin 7-9 g/dL and serum ferritin $<15 \mathrm{ng} / \mathrm{mL}$, compared ferrous sulfate with intravenous iron sucrose infusion. They also have reported a statistically significant difference in the increase of hemoglobin levels $(\mathrm{p}=0.002)$ and ferritin levels on day 30 in the intravenous iron group compared to the oral iron group $(\mathrm{p}=0.005){ }^{[22]}$ On the other side, a randomized study comparing two different doses of intravenous iron with $80 \mathrm{mg}$ ferrous sulfate daily in 260 pregnant women did not find clinically significant benefit for the parental route in iron prophylaxis of anemia. In the first intravenous iron group, 75 women received two doses of $200 \mathrm{mg}$ iron sucrose and in the second intravenous iron group, 55 women received three doses of $200 \mathrm{mg}$ iron sucrose. Only in the second intravenous iron group with three doses a significant rise in serum ferritin levels were reported. However, they did not use a standard dose and timing of oral iron prophylaxis. Besides, women included in this study were nonanemic by the time of the recruitment opposite to the former studies mentioned above.

A disadvantage of ferric carboxymaltose is its cost. In Turkey, it is 6 times more expensive than six-month oral iron supplementation. Moreover, intravenous iron infusion requires a hospital setting. Therefore, it is not possible to advocate the routine use of intravenous iron for all pregnant women. The advantage of ferric carboxymaltose is its efficiency and quick response.
The main limitations of our study are its retrospective design and small sample size. In order to minimize selection bias, we included all the women who were given intravenous iron supplementation within the study period. Another limitation of our study is that we were not able to measure patients' compliance with oral supplements.

Although ferric carboxymaltose seems efficient, costeffectiveness analysis, risk analysis, and randomized controlled trials are required before suggesting routine use instead of oral iron in pregnancy.

\section{Conclusion}

Intravenous ferric carboxymaltose administration seems an effective, easy-to-use option for iron supplementation during pregnancy. From a practical point of view, intravenous iron supplementation seems to be an acceptable alternative especially for pregnant women who cannot tolerate oral iron treatment or who have very low ferritin levels and severe anemia.

Funding: This work did not receive any specific grant from funding agencies in the public, commercial, or not-for-profit sectors.

Compliance with Ethical Standards: The authors stated that the standards regarding research and publication ethics, the Personal Data Protection Law and the copyright regulations applicable to intellectual and artistic works are complied with and there is no conflict of interest.

\section{References}

1. Means RT. Iron deficiency and iron deficiency anemia: implications and impact in pregnancy, fetal development, and early childhood parameters. Nutrients 2020;12:447. [PubMed] [CrossRef]

2. Levy A, Fraser D, Katz M, Mazor M, Sheiner E. Maternal anemia during pregnancy is an independent risk factor for low birthweight and preterm delivery. Eur J Obstet Gynecol Reprod Biol 2005;122:182-6. [PubMed] [CrossRef]

3. Sultan P, Bampoe S, Shah R, Guo N, Estes J, Stave C, et al. Oral vs intravenous iron therapy for postpartum anemia: a systematic review and meta-analysis. Am J Obstet Gynecol 2019;221:19-29.e3. [PubMed] [CrossRef]

4. Breymann C. Iron deficiency anemia in pregnancy. Semin Hematol 2015;52:339-47. [PubMed] [CrossRef]

5. Breymann C, Honegger C, Hösli I, Surbek D. Diagnosis and treatment of iron-deficiency anaemia in pregnancy and postpartum. Arch Gynecol Obstet 2017;296:1229-34. [PubMed] [CrossRef]

6. Api O, Breyman C, Cetiner M, Demir C, Ecder T. Diagnosis and treatment of iron deficiency anemia during pregnancy and 
the postpartum period: iron deficiency anemia working group consensus report. Turk J Obstet Gynecol 2015;12:173-81. [PubMed] [CrossRef]

7. Milman N. Iron in pregnancy: how do we secure an appropriate iron status in the mother and child? Ann Nutr Metab 2011;59:50-4. [PubMed] [CrossRef]

8. American College of Obtetrics and Gynecologists' Committee on Practice Bulletins-Obstetrics. Anemia in pregnancy: ACOG Practice Bulletin, Number 233. Obstet Gynecol 2021; 138:e55-e64. [PubMed] [CrossRef]

9. Auerbach M. Commentary: Iron deficiency of pregnancy - a new approach involving intravenous iron. Reprod Health 2018;15(Suppl 1):96. [PubMed] [CrossRef]

10. Scott LJ. Ferric carboxymaltose: a review in iron deficiency. Drugs 2018;78:479-93. [PubMed] [CrossRef]

11. Auerbach M, Macdougall IC. Safety of intravenous iron formulations: facts and folklore. Blood Transfus 2014;12:296-300. [PubMed] [CrossRef]

12. Chertow GM, Mason PD, Vaage-Nilsen O, Ahlmen J. Update on adverse drug events associated with parenteral iron. Nephrol Dial Transplant 2006;21:378-82. [PubMed] [CrossRef]

13. Vanobberghen F, Lweno O, Kuemmerle A, Mwebi KD, Asilia $\mathrm{P}$, Issa A, et al. Efficacy and safety of intravenous ferric carboxymaltose compared with oral iron for the treatment of iron deficiency anaemia in women after childbirth in Tanzania: a parallel-group, open-label, randomised controlled phase 3 trial. Lancet Glob Health 2021;9:e189-e98. [PubMed] [CrossRef]

14. Achebe MM and Gafter-Gvili A. How I treat anemia in pregnancy: iron, cobalamin, and folate. Blood 2017;129:940-49. [PubMed] [CrossRef]

15. Wang C, Graham DJ, Kane RC, Xie D, Wernecke M, Levenson $\mathrm{M}$, et al. Comparative risk of anaphylactic reactions associated with intravenous iron products. JAMA 2015;314: 2062-8. [PubMed] [CrossRef]

16. Al RA, Unlubilgin E, Kandemir O, Yalvac S, Cakir L, Haberal A. Intravenous versus oral iron for treatment of anemia in pregnancy: a randomized trial. Obstet Gynecol 2005;106:1335-40. [PubMed] [CrossRef]

17. Khalafallah A, Dennis A, Bates J, Bates G, Robertson IK, Smith $\mathrm{L}$, et al. A prospective randomized, controlled trial of intravenous versus oral iron for moderate iron deficiency anaemia of pregnancy. J Intern Med 2010;268:286-95. [PubMed] [CrossRef]

18. Froessler B, Gajic T, Dekker G, Hodyl NA. Treatment of iron deficiency and iron deficiency anemia with intravenous ferric carboxymaltose in pregnancy. Arch Gynecol Obstet 2018;298: 75-82. [PubMed] [CrossRef]

19. Froessler B, Collingwood J, Hodyl NA, Dekker G. Intravenous ferric carboxymaltose for anaemia in pregnancy. BMC Pregnancy Childbirth 2014;14:115. [PubMed] [CrossRef]

20. Mishra V, Gandhi K, Roy P, Hokabaj S, Shah KN. Role of intravenous ferric carboxy-maltose in pregnant women with iron deficiency anaemia. J Nepal Health Res Counc 2017;15: 96-9. [PubMed] [CrossRef]

21. Breymann C, Milman N, Mezzacasa A, Bernard R, Dudenhausen J; FER-ASAP Investigators. Ferric carboxymaltose vs. oral iron in the treatment of pregnant women with iron deficiency anemia: an international, open-label, randomized controlled trial (FER-ASAP). J Perinat Med 2017;45:443-53. [PubMed] [CrossRef]

22. Kochhar PK, Kaundal A, Ghosh P. Intravenous iron sucrose versus oral iron in treatment of iron deficiency anemia in pregnancy: a randomized clinical trial. J Obstet Gynaecol Res 2013; 39:504-10. [PubMed] [CrossRef]

This work is licensed under the Creative Commons Attribution-NonCommercial-NoDerivs 4.0 Unported (CC BY-NC-ND4.0) License. To view a copy of this license, visit http://creativecommons.org/licenses/by-nc-nd/4.0/ or send a letter to Creative Commons, PO Box 1866, Mountain View, CA 94042 , USA.

Publisher's Note: The content of this publication does not necessarily reflect the views or policies of the publisher, nor does any mention of trade names, commercial products, or organizations imply endorsement by the publisher. Scientific and legal responsibilities of published manuscript belong to their author(s). The publisher remains neutral with regard to jurisdictional claims in published maps and institutional affiliations. 